\title{
DASAR PELAKSANAAN DAN KARAKTERISTIK DOKUMENTASI DALAM KEPERAWATAN
}

\author{
Agnes Jessica Lubis \\ Jessikaagnes8@gmail.com
}

\section{Latar belakang}

Dokumentasi pengkajian keperawatan merupakan catatan tentang hasil pengkajian yang dilaksanakan untuk mengumpulkan informasi dari pasien, membuat data dasar tentang pasien, dan membuat catatan tentang respons kesehatan pasien. Pengkajian yang komprehensif atau menyeluruh, sistematis yang logis akan mengarah dan mendukung pada identifikasi masalahmasalah pasien. Masalah-masalah ini dengan menggunakan data penkajian sebagai dasar formulasi yang dinyatakan sebagai diagnosa keperawatan.

Dokumentasi merupakan bukti pencatatan dan pelaporan yang dimiliki perawat dalam catatan yang berguna untuk kepentingan klien, perawat dan tim kesehatan dalam memberikan pelayanan kesehatan dengan dasar data yang akurat dan lengkap secara tertulis sebagai tanggung jawab perawat (Wahid \& Suprapto,2012).

Pendokumentasian asuhan keperawatan juga dapat digunakan sebagai tanggung jawab dan tanggung gugat dari berbagai kemungkinan masalah yang akan dialami oleh pasien atau klien baik masalah kepuasan maupun ketidak puasan terhadap pelayanan kesehatan yang diberikan (Nursalam,2001).

Pelaksanaan dokumentasi keperawatan sebagai salah satu alat ukur untuk mengetahui, memantau dan menyimpulkan suatu pelayanan asuhan keperawatan yang diselenggarakan di rumah sakit (Fisbach,1991 dalam Setiadi,2012).

Pedokumentasian asuhan keperawatan yang tepat waktu, akurat dan lengkap tidak hanya penting untuk melindungi perawat tetapi penting juga untuk membantu pasien atau klien mendapat asuhan keperawatan yang lebih baik (Depkes RI,1996).

Pendokumentasian bagi rumah sakit sangat penting dalam meningkatkan standar akreditasi, sebagai alat komunikasi antar profesi, indikator pelayanan mutu, bukti tanggung jawab, dan 
tanggung gugat perawat, sumber data dan sebagai sarana penelitian (Teytelman, 2002; Jefferies, Johnson, Nicholls \& Lad, 2012).

Dokumentasi dalam keperawatan merupakan suatu hal yang perlu adanya peningkatan dikarenakan pentingnya dokumentasi dalam keperawatan. Sejak zaman Florence Nightingale telah ditetapkannya bahwa dokumentasi merupakan salah satu fungsi yang paling penting dikarenakan dapat menjadi jaminan kelangsungan perawatan dan dapat juga berfungsi sebagai bukti hokum dari proses perawatan serta mendukung evaluasi kualitas pada perawatan pasien,

\section{Metode}

Metode ini digunakan secara faktual dengan merujuk pada referensi referensi yang dapat dipercaya seperti contohnya ialah jurnal, e-book, serta buku teks . Dengan menggabungkan referensi referensi yang faktul tentang dokumentasi maka berharap artikel ini dapat membantu orang orang yang membutuhkan informasi tentang dokumentasi dalam keperawatan dan tidak menganggap sepele hal tentang dokumentasi.

\section{Hasil}

Setiap tindakan yang dilakukan oleh perawat memiliki tanggung jawab tersendiri dengan menyertakan pendokumentasian sehingga asuhan keperawatan tersebut dapat berjalan baik sesuai kaidah ataupun aturan aturan yang sudah ditentukan dan kewajiban tersebut sudah disadari oleh perawat itu sendiri.

Pada masa masa ini tak dapat dipungkiri pula bahwa sebagian besar perawat diindonesia belum memberikan pelayanan keperawatan sesuai dengan asuhan keperawatan, yang salah satu penyebabnya ialah pendokumentasian yang tidak lengkap.

Menurut Sugiharto, Keliat, dan Hariyati (2012) menyatakan bahwa perawat dalam melakukan pekerjaannya kerap menyebabkan demotivasi yang disebabkan oleh beberapa hal seperti jam kerja yang panjang, dampak jam kerja malam, kekurangan tenaga keperawatan karena beban kerja tinggi, gaji rendah, dan kurangnya penghargaan.

Tujuan dari Pendokumentasian itu tersebut ialah untuk Mengkomunikasikan data klien ke semua anggota tim kesehatan sehingga tidak terjadi data yang salah dalam memberikan asuhan 
keperawatan, untuk jadi bukti guna tujuan evaluasi hasil dari implementasi asuhan keperawatan, dan Untuk jaminan kepada masyarakat tentang lingkup dan mutu pelayanan keperawatan dan membuktikan pekerjaan perawatan serta meningkatkan tanggung gugat perawat, serta dapat menjadi sumber data untuk melakukan penelitian.

Manfaat lainnya ialah setelah mendapatkan data pasien dan melakukan hal hal sesuai dengan standar asuhan keperawatan dan kemudian mendapat tuntutan secara hukum maka perawat dapat menggunakan pendokumentasian yang lengkap dan dapat menghilangkan berita berita yang tidak benar.

Pendokumentasian baik tentang identitas pasien maupun keluhanpasien tentang apa yang dirasakannya dapat berguna untuk membantu kesembuhan pasien dengan bantuan dari perawat dengan standar asuhan keperawatan yang sudah ditentukan.

Maka dari itu perawat harus memperhatikan hal penting seperti pendokumentasian dengan sesuai standar asuhan keperawatan yang sudah ditetapkan,

Ada pula Upaya untuk meningkatkan kualitas dari pelaksanaan pendokumentasian ialah dengan melaksanakan audit dokumentasi. Audit dokumentasi dilakukan dengan cara membandingkan pendokumentasian yang ditemukan dalam rekam medik pasien dengan standar pendokumentasian yang ditentukan dalam standar asuhan keperawatan.

\section{Pembahasan}

Menurut Sugiharto, Keliat, dan Hariyati (2012) menyatakan bahwa perawat dalam melakukan pekerjaannya kerap menyebabkan demotivasi yang disebabkan oleh beberapa hal seperti jam kerja yang panjang, dampak jam kerja malam, kekurangan tenaga keperawatan karena beban kerja tinggi, gaji rendah, dan kurangnya penghargaan.

Tujuan dari Pendokumentasian itu tersebut ialah untuk Mengkomunikasikan data klien ke semua anggota tim kesehatan sehingga tidak terjadi data yang salah dalam memberikan asuhan keperawatan, untuk jadi bukti guna tujuan evaluasi hasil dari implementasi asuhan keperawatan, dan Untuk jaminan kepada masyarakat tentang lingkup dan mutu pelayanan keperawatan dan membuktikan pekerjaan perawatan serta meningkatkan tanggung gugat perawat, serta dapat menjadi sumber data untuk melakukan penelitian. 
Dalam melaksanakan dokumentasi pada tahap pengkajian perlu diketahui bahwa jenis dokumentasi keperawatan meliputi:

1. Dokumentasi pada saat pengkajian awal (InitialAssessment) Dokumentasi yang dibuat ketika pasien pertama kali masuk rumah sakit. Data yang dikaji pada pasien berupa data awal yang digunakan sebagai dasar dalam pemberian asuhan keperawatan.

2. Dokumentasi pengkajian lanjutan (Ongoing Assessment) Data pada dokumentasi ini merupaka pengembangan dasar yang dilakukan untuk melengkapi pengkajian awal dengan tujuan semua data menjadi lengkapsehingga mendukung infromasi tentang permasalahan kesehatan pasien. Hasil pengkajian ini dimasukkan dalam catatan perkembangan terintegrasi pasien atau pada lembar data penunjang.

3. Dokumentasi pengkajian ulang (Reassessment) Dokumentasi ini merupakan pencatatan terhadap hasil pengkajian yang didapat dari informasi selama evluasi. Perawat mengevauasi kemajuan dta terhadap pasien yang sudah ditentukan.

Dalam pengkajian keperawatan terdapat jenis data yang dapat diperoleh, yaitu data Subjektif. Data subjektif itu sendiri diperoleh dari hasil pengkajian terhadap pasien dengan teknik wawancara, keluarga, konsultan, dan tenaga kesehatan lainnya serta riwayat keperawatan. Data ini berupa keluhan atau persepsi subjektif pasien terhadap status kesehatannya.

Selanjutnya Data Objektif, Informasi data objektif diperoleh dari hasil observasi, pemeriksaan fisik, hasil pemeriksaan penunjang dan hasil laboratorium. Fokus dari pengkajian data objektif berupa status kesehatan, pola koping, fungsi status respons pasien terhadap terapi, risiko untuk masalah potensial, dukungan terhadap pasien. Karakteristik data yang diperoleh dari hasil pengkajian seharusnya memiliki karakteristik yang lengkap, akurat, nyata dan relevan. Data yang lengkap mampu mengidentifikasi semua masalah keperawatan pada pasien.

Diagnosa keperawatan adalah keputusan klinis mengenai seseorang, keluarga, atau masyarakat sebagai akibat dari masalah kesehatan atau proses kehidupan yang aktual atau potensial. Diagnosa keperawatan merupakan dasar dalam penyusunan rencana tindakan asuhan keperawatan.Diagnosis keperawatan sejalan dengan diagnosis medis sebab dalam 
mengumpulkan data-data saat melakukan pengkajian keperawatan yang dibutuhkan untuk menegakkan diagnosa keperawatan ditinjau dari keadaan penyakit dalam diagnosa medis.

Diagnosa keperawatan adalah keputusan klinis mengenai seseorang, keluarga, atau masyarakat sebagai akibat dari masalah kesehatan atau proses kehidupan yang aktual atau potensial.

Diagnosa keperawatan merupakan dasar dalam penyusunan rencana tindakan asuhan keperawatan, sangat perlu untuk didokumentasikan dengan baik.Dalam Topik ini diuraikan bagaimana melakukan pendokumentasian pada tahap diagnosis.Dengan mempelajari Topik 2 ini Anda diharapkan mampu mempraktekkan Pendokumentasian pada tahap pengkajian

Perencanaan keperawatan adalah suatu rangkaian kegiatan penentuan langkahlangkah pemecahan masalah dan prioritasnya, perumusan tujuan, rencana tindakan dan penilaian asuhan keperawatan pada pasienberdasarkan analisis data dan diagnosa keperawatan.

perawat pernah tidak membuat pendokumetasian asuhan keperawatan, karena perawat memilik kesibukan yang tinggi. Kepala ruangan akan memberikan teguran dan meminta untuk melengkapi pendokumentasian. Perawat akan mengingatkan dan menyarankan temannya untuk melengkapi pendokumentasian asuhan keperawatan jika ada yang belum lengkap. Tidak ada imbalan khusus untuk pendokumentasian asuhan keperawatan. Pendokumentasian yang ada sudah sesuai dengan pedoman yang ada. Pendokumentasian memiliki peran yang sangat penting. Hambatannya adalah format tulisan yang kecil, terlalu banyak, kurang pegawai atau SDM dan kurangnya motivasi.

Dokumentasi keperawatan merupakan bukti pencatatan dan pelaporan yang dimiliki perawat dalam melakukan catatan keperawatan yang berguna untuk kepentingan klien, perawat dan tim kesehatan dalam memberikan pelayanan kesehatan. Desain penelitian adalah survei analitik dengan pendekatan cross sectional. Sampel berjumlah 173 perawat dari 14 ruang rawat dan lembar observasi kelengkapan dokumentasi berjumlah 80 dokumen. Hasil penelitian menunjukkan bahwa pelaksanaan dokumentasi keperawatan dalam kriteria baik sebesar 47,4\% dan perawat yang melengkapi dokumentasi keperawatan sebesar 57,2\%.

Sedangkan faktor yang paling berkontribusi secara bermakna dengan kelengkapan dokumentasi keperawatan adalah Ruang Dinas $(\mathrm{p}=0,002 ; \alpha=0,05)$ setelah dikontrol oleh umur, jenis kelamin, tingkat pendidikan, dan tipe kelas ruangan. Diharapkan bidang perawatan dapat melengkapi 
dokumentasi keperawatan dengan format yang sama, memberi kesempatan perawat untuk melanjutkan kuliah dan mengikuti pelatihan askep serta bertukar informasi atau gagasan antar ruang rawat.

Beberapa faktor yang dapat menyebabkan bahwa pendokumentasian tidak dilengkapi yaitu

- Usia, dimana perawat yang sudah memiliki pengalaman cukup lama dengan umur kurang lebih 28 keatas akan melakukan pendokumentasian dengan lengkap dibandingkan dengan perawat yang kurang dari 28 tahun. Hal ini memperlihatkan bahwa hubungan antara umur dan kinerja merupakan isu penting, karena terdapat keyakinan bahwa kinerja akan merosot dengan bertambahnya umur (Robbin, 2006). Akan tetapi, hasil penelitian ini merubah keyakinan tersebut. Penelitian ini didukung pendapat Gibson (1996) dalam Suratun (2008) yang mengemukakan bahwa pekerja yang lebih tua dianggap lebih cakap secara teknis, lebih banyak pengalaman dan lebih bijaksana dalam pengambilan keputusan.

- Tingkat pendidikan, kemungkinan besar bahwa perawat yang berpendidikan DIII Keperawatan mendokumentasikan asuhan keperawatan lengkap sebesar 58,6\% dibanding dengan SPK (36,4\%). Hal ini sesuai dengan pendapat Gibson (1996) dalam Suratun (2008) yang mengemukakan bahwa tingkat pendidikan yang tinggi umumnya menyebabkan seseorang lebih mampu dan bersedia menerima tanggung jawab. Sedangkan Siagian (2002) menjelaskan bahwa makin tinggi pendidikan seseorang makin besar keinginan untuk memanfaatkan pengetahuan dan keterampilan. Penelitian ini didukung pula oleh penelitian Fizran dan Mamdy (2002) yang mendapatkan bahwa tingkat pendidikan berhubungan secara bermakna dengan kinerja perawat dalam pendokumentasian keperawatan serta penelitian Usman dan Tafal (2002) yang mengemukakan bahwa tingkat pendidikan berhubungan secara bermakna dengan motivasi perawat dalam penerapan proses keperawatan

- Lama kerja, perawat yang bekerja lebih dari 10 Tahun melakukan pendokumentasian keperawatan dengan lengkap sebesar 60,0\%. Hal ini sesuai dengan pendapat Robbins (2006) dalam Suratun (2008) yang menyatakan terdapat suatu hubungan yang positif antara masa kerja dan produktifitas pekerjaan. Makin lama seseorang bekerja makin terampil dan berpengalaman melaksanakan pekerjaannya. Lama kerja menjadi sangat 
penting karena dapat mencerminkan tingkat kepuasan akhir yang dapat dicapai oleh karyawan. Hal ini didukung pula oleh penelitian Hotnida dan Sumiatun (2002) yaitu faktor lama kerja berpengaruh terhadap kinerja perawat dalam pendokumentasian proses keperawatan.

- Pengetahuan terkait Dokumentasi Keperawatan, perawat yang pengetahuannya terkait dokumentasi keperawatan rendah, ada sejumlah 58,3\% yang dokumentasi keperawatannya lengkap. Sedangkan perawat yang memiliki pengetahuan dokumentasi keperawatan tinggi, ada sebanyak 56,2\% yang dokumentasi keperawatannya lengkap. Hal ini bertentangan dengan penelitian Fizran dan Mamdy (2002) yang mendapatkan bahwa tingkat pengetahuan berhubungan secara bermakna dengan kinerja perawat dalam pendokumentasian keperawatan. Begitu pula dengan penelitian Kusumawaty dan Yani (2001) yang mendapatkan bahwa adanya hubungan bermakna dan berpola positif antara pemahaman terhadap pendokumentasian proses keperawatan dengan kompetensi mendokumentasikan proses keperawatan. Asumsi peneliti menyatakan bahwa pengetahuan tinggi tidak selalu menunjukkan pelaksanaan dokumentasi keperawatan yang lengkap.

\section{Penutup}

\section{a.kesimpulan}

Dokumentasi keperawatan merupakan bukti pencatatan ataupun pelaporan yang dimiliki perawat dalam melakukan catatan keperawatan yang berguna untuk kepentingan klien, perawat dan tim kesehatan dalam memberikan pelayanan kesehatan. Desain penelitian adalah survei analitik dengan pendekatan cross sectional. Pendokumentasian dalam keperawatan merupakan hal yang sangat penting untuk menjadi bukti jika terjadi kesalah pahaman antara pasien terhadap perawat sehingga tidak terjadi timpah tindih yang dapat menyalahkan perawat .

b. saran

untuk mahasiswa keperawatan maupun yang sudah profesi diharpkan untuk memenuhi betapa pentingnya pendokumentasian meskipun sedikit ribet ataupun dianggap sederhana namun pendokumentasian hal yang sangat berguna untuk perawat itu sendiri. 


\section{Daftar pustaka}

Setiadi. (2012). Konsep \& Penulisan Dokumentasi Asuhan Keperawatan Teori dan Praktik. Yogyakarta : Graha Ilmu

mulyanti dinarti yuli (2017), dokumentasi keperawatan .Kementrian kesehatan republik indonesia.

Ghofur, Abdul. [2013]. " Standar dan Model Dokumentasi Keperawatan ", https://www.slideshare.net/pji_kemenkes/modul-2-dokumen-keperawatan-kb4- 43683413,

Aba, M. Hartono, B. Dkk. (2018). Analisis Organisasi dalam Pendokumentasian Asuhan Keperawatan di Ruang Rawat Inap Cendrawasi RSUD ARI. 12(11)

Noorkasiani. Gustina. R. Siti Maryam. (2015). Faktor-faktor yang Berhubungan dengan Kelengkapan Dokumentasi Keperawatan. Jurnal Keperawatan Indonesia. 18(01). 1-8

Sari, D. P., \& Siwi, G. R. (2019). Hubungan Antara Pengetahuan Perawat Tentang Rekam Medis dan Dokumentasi Keperawatan Dengan Kelengkapan Pencatatan Dokumentasi Keperawatan di Klinik MTA Surakarta 2019. Infokes Journal, 9(1), 45- 49.

Zakiyah, A. (2015). Hubungan Sikap dan Karakteristik Perawat Dengan Pendokumentasian Asuhan Keperawatan di Rumah Sakit Umum Sidoarjo. Jurnal Keperawatan Sehat, 5(01).

Wulandini, P., Krianto, T., \& Priwahyuni, Y. (2016). Faktor-Faktor yang Berhubungan Dengan Perilaku Pendokumentasian Asuhan Keperawatan di RSJ Tampan Pekanbaru Tahun 2014. NERS Jurnal Keperawatan, 12(2), 131-142.

Supratti, S., \& Ashriady, A. (2018). Pendokumentasian Standar Asuhan Keperawatan Di Rumah Sakit Umum Daerah Mamuju. Jurnal Kesehatan Manarang, 2(1), 44-51.

Yeni, F. (2014). Pengaruh Pelatihan Proses Keperawatan terhadap Dokumentasi Asuhan Keperawatan di Puskesmas Kabupaten Agam Propinsi Sumatera Barat. NERS Jurnal Keperawatan, 10(1), 24-31.

Simamora, R. (2009). Dokumentasi Proses Keperawatan 
Simamora, R. H., Purba, J. M., Bukit, E. K., \& Nurbaiti, N. (2019). Penguatan Peran

Perawat Dalam Pelaksanaan Asuhan Keperawatan Melalui Pelatihan Layanan Prima. JPPM (Jurnal Pengabdian Dan Pemberdayaan Masyarakat), 3(1), 25-31. 